\title{
TRANSFER OF INFORMATION, KNOWLEDGE AND INNOVATIONS IN RURAL AREAS
}

\author{
Edyta Kulej-Dudek, Anna Wiśniewska-Sałek \\ Czestochowa University of Technology, Poland
}

\begin{abstract}
This article discusses the concept and role of information, knowledge and innovations in the aspect of the economic growth. The main types of innovation were emphasized. The activities aimed at implementation of the strategy of intelligent and sustainable development were specified. The challenges and priorities of common development policies for regions were discussed, with particular focus on rural areas. Furthermore, the chapter presents author's own survey on diffusion, transfer and absorption of information, knowledge and innovations in rural areas.
\end{abstract}

Keywords: information, knowledge, innovations, transfer, diffusion, rural areas

DOI: 10.17512/znpcz.2016.1.16

\section{Introduction}

Nowadays, widespread globalization, the increase in the amount of information and knowledge and processes of economic transformations lead to the intensive development of modern civilization through fast rate of changes in the business environment of enterprises. Continuous increase in information and knowledge drives the need for processing information and use it for current activities of each enterprise that has to face new challenges. Globalization and technological changes stimulate development of knowledge-based economy, where knowledge and information are becoming the most important factors in progress, development and competitiveness. In current economy, characterized by dynamic environment and greater amount of new products, industrial competition has yielded to information competition.

Scientific discoveries and technological innovations contributed to the emergence of a new paradigm in information and technology. Its specific nature consists in that information represents both the primary material and a final product for the process of creating innovation. The sectors of modern technologies are focused on processing information. Therefore, information is the most basic primary material, whereas technological innovation concern in particular the methods (Evans 2005, p. 22)]. Methods used to take actions relate directly to human activity while information and knowledge are becoming a basic source of economic value and competitive advantage. Previous economy was based on condensation of resources, i.e. integration of a large amount of primary products and materials by means of little knowledge while the new economy is based on 
condensation of knowledge (Davenport, Prusak 1998, p. 17). Knowledge represents the source of constant competitive advantage under condition that, contrary to other resources, it extends through utilization.

According to Davenport and Prusak, ,ideas give birth to other ideas and, sharing knowledge, we do not consume it but rather help enrich others" (Davenport, Prusak 1998, p. 17). The advantage of enterprises is ensured by concentration on knowledge extension and continuous development of competencies. A competitive advantage is formed only when the enterprise can generate new knowledge through creation of a climate that is conducive to learning. In order to become competitive, the enterprise has to ensure high quality of services, innovativeness and market-oriented adjustment to varied expectations. These activities should be supported by utilization of modern IT tools, technologies and systems that allow for collection, storage, transfer and utilization of huge amounts of data and information from a number of internal and external sources.

Transitions observed in recent years have brought a fast and virtually unlimited flow of information and knowledge, flow of employees in the labour market and popularization of new concepts of enterprise management. These changes are connected with a new type of the economy, where production, distribution and utilization of knowledge is the main driving force for growth, creation of wealth and employment across various industries. Knowledge-based economy is based on resources and utilization of knowledge potential, which represent the strategic factors of its development [Skrzypek 2004, p. 14]. In knowledge-based economy, people without competencies, those who are unable to learn new competencies and skills and those who do not invest in continuous improvement may be considered as less valuable employees. Knowledge-based economy forces enterprises to implement changes connected with employing highly-qualified staffs, care for knowledge quality and continuous extending and deepening the knowledge (KulejDudek 2012, p. 94-111).

Therefore, the aim of this chapter is to present the role of information, knowledge and innovation as components that affect both economic growth and competitiveness. It is also important to identify challenges and prospects for development in rural areas and indicate the actions that can be taken to support inhabitants in these areas.

\section{Information, knowledge and innovations as factors of development and competitiveness}

Under conditions of new economies, the sources of innovativeness include organizational knowledge, tacit knowledge and employees' competencies (Lis, Brzozowska, Korombel 2013, p. 262-267). The constant process of economic transformations affects searching and implementation of innovations and methods of management that improve enterprise's capability of faster and comprehensive adaptation to changes in the environment. Searching for sources of competitive advantage of enterprises involves non-physical resources in the form of employee competencies, knowledge and skills (Kaczmarek, 2007, p. 15). 
Prof. Grudzewski and Prof. Hejduk argues that information should be understood to mean organized data which are created through categorization and classification of data and giving them a specific context in order to utilize them (Grudzewski, Hejduk 2004, p. 75-76). Furthermore, "knowledge means the use of information in practice" (Grudzewski, Hejduk 2002, p. 16.). Therefore, knowledge represents a full utilization of information and data connected with potential of human skills, abilities, ideas, commitment and motivation (Grudzewski, Hejduk 2004, p. 75-76). Prof. Kisielnicki defines knowledge as non-physical organizational resources connected with human activity while using them may become the basis for competitive advantage in the organization. It is connected with resources in the form of data, information, procedures, experience and education (Kisielnicki 2003, p. 17). G. Probst et al., consider knowledge as a set of pieces of information and skills used by the entity to solve problems. It includes both theoretical and practical components, general principles and specific guidelines. Knowledge is always related to a specific person. It is generated by individuals and represents their beliefs concerning cause-and-effect relationships (Probst, Raub, Romhardt 2002, p. 35).

Knowledge is regarded as a particularly valuable commodity, contained not only in the products manufactured but also in the tacit knowledge of highlyqualified employees. This knowledge is usually "hidden" in the minds of individual persons and can be shared with other people through codification, conversations, stories, working together or documented consciously in other manner. The process of knowledge externalization is an essential component of management of this resource. Finding the most efficient and effective methods to utilize and share knowledge represents a key task in achievement of enterprise's goals.

Efficient actions in terms of information and knowledge transfer between different entities (employees, enterprises, institutions) should focus on such processes as: creation of a new knowledge, identification of internal and external sources of knowledge, using available knowledge and incorporating the knowledge into processes, products, services, innovations, documents, databases and software, stimulating knowledge development through support for sharing knowledge.

In the era of globalization, the importance of technology and innovations is increasing while they are becoming major factors that determine competitiveness of regions ( Sałek 2013, p. 90-101). The term innovativeness is one of the most frequent terms used in the context of development, competitiveness and economic growth. Innovativeness is particularly important for building competitive advantage and determination of business processes.

Innovations are new ideas which allow for gaining competitive advantage in the market through changes in management and production processes. Four major types of innovations are (Zasady gromadzenia i interpretacji danych dotyczacych innowacji. Podręcznik Oslo, 2008, p. 49-53):

- product innovations - launching products or services which are new or substantially improved in terms of their characteristics and application e.g. considerable improvements in terms of technical specifications, components and materials, software, user-friendliness or other functional features, 
- process innovations - innovations in the area of process mean implementation of a new or substantially improved method of production and supply e.g. substantial changes in terms of technology, devices and/or software,

- marketing innovation - implementation of a new marketing method involving significant changes in product design or packaging, product placement, product promotion or pricing.

- organizational innovation - implementation of a new organisational method in the firm's business practices, workplace organisation or external relations.

Social innovations also seem to be important. They are defined as social initiatives aimed at improvement of quality of living of people, communities, nations, enterprises, environments and social groups (Budinich, Serneels 2012). Social innovations concern innovative activities in the area of social problems and the process of creation of innovative solutions for social utilization (Stanowisko Ogólnopolskiej Federacji Organizacji Pozarządowych w sprawie innowacji społecznych 2012, p. 1). They are connected with open access to resources, the use of modern technologies, modern forms of collaboration and creativity. Their overriding goal is to implement social changes and popularize these changes in the form of good practices.

\section{Challenges and prospects for developmental changes contained in strategic documents}

One of the main strategic documents that emphasize the role of information, knowledge and innovation is Strategy for intelligent and sustainable development, with one of the priorities to be implemented by 2020 being intelligent development i.e. development of the economy based on knowledge and innovation. Intelligent development is considered as increasing the role of knowledge and innovations as a driving force for future development. This requires improving the quality of education, improving the results of research activities, supporting innovation transfer and knowledge, full utilization of information and communication technologies and ensuring that innovative ideas are transformed into new products and services which contribute to the increased growth, creation of new workplaces and solving social (Europa 2020, 2010, p. 11-13) problems.

Another document that points to similar problems is the National Regional Development Strategy for 2010-2020. The strategic objective of regional policy defined in this strategy is efficient utilization of specific regional and territorial potential for development to achieve goals of national development: growth, employment and cohesion in long-term horizon. Specific goals also emphasize supporting the growth of competitiveness in regions and building territorial cohesion while preventing marginalization in problem-generating areas (Krajowa Strategia Rozwoju Regionalnego 2010-2020, 2010, p. 5).

The program for development of rural areas for 2014-2020 (Program rozwoju obszarów wiejskich na lata 2014-2020) defined six priorities of common policy of development in rural areas, where the focus was on facilitation of transfer of knowledge and innovations, promotion of innovative technologies and economic growth in rural areas (Program rozwoju obszarów wiejskich na lata 2014-2020, p. $79,81,156)$. 
The problems presented in the chapter were a stimulus for starting the research in this area. The target group of enterprises was analysed using a survey questionnaire and individual interviews with representatives of enterprises with adequate level of knowledge about the research problem. The study focused on eighty four SME enterprises in the Czestochowa region of Poland from various industries.

Respondents were asked to express their opinions about the problems observed by them in rural areas (see figure 1). The highest percentage of respondents indicated the poor access to specialized medical, banking and educational services (79\%), and limited opportunities for improving education, continuous learning and vocational training (75\%). Other indications included insufficient number of competent and well-qualified employees (67\%) and insufficient information and knowledge in terms of entrepreneurship, innovativeness and competitiveness (63\%).

insufficient information and knowledge about entrepreneurship,...

high unemployment rate

poor availability and quality of information technologies and the...

insufficient number of competent and well-qualified employees

poor access to specialized medical, banking and educational services

moving from rural to urban areas

limited opportunities for improving education, lifelong learning and...

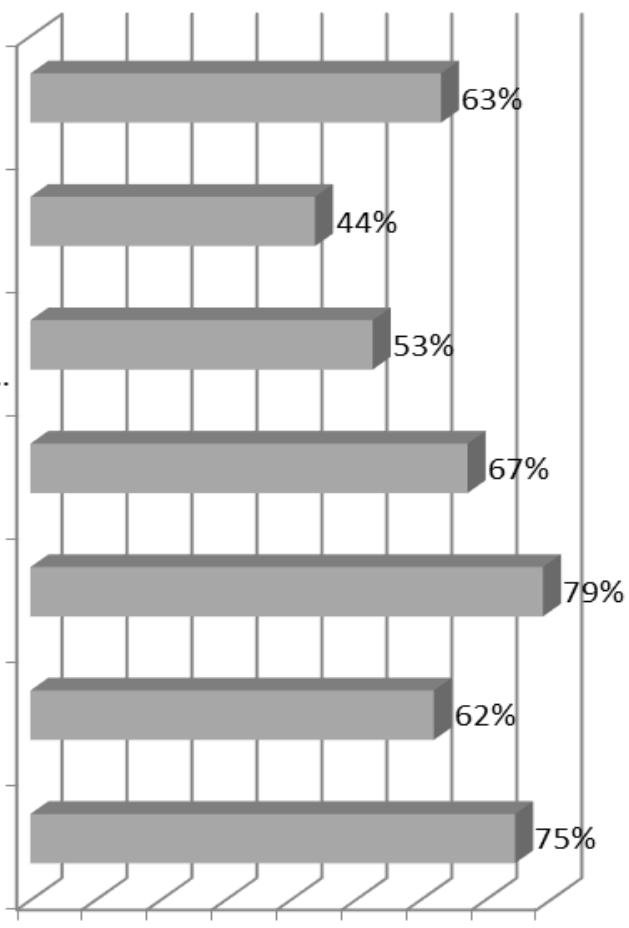

0\% 10\% 20\% 30\% 40\% 50\% 60\% 70\% 80\%

Figure 1. Noticeable problems in rural areas

Source: Author's own elaboration. 
One of the challenges that relate to spatially-oriented problems is to increase developmental opportunities in rural areas characterized by the worst socioeconomic indices and the lowest level of access to services and goods that determine development opportunities. The adverse indices that determine developmental opportunities include: very high level of employment in agriculture, low entrepreneurship, high employment rate among people with low level of education and low professional competencies, underinvestment and low level of infrastructural facilities. The phenomenon of outflow of people at the working age (with particular focus on women and young people) from rural areas should also be emphasized. Poor or difficult access of rural inhabitants to public goods and services represents a substantial obstacle in development of these areas. Insufficient quality of educational infrastructure and low level of education causes a decline in quality of human capital and substantially reduces chances of students from these areas to study at attractive and modern university majors that help being competitive in the labour market (Dudek 2015, p.80-88). Furthermore, people that start learning expect personalized curricula, close cooperation and relationships between formal and informal learning, which is largely possible through learning using ICT technologies (Dudek 2015, p.80-88). Therefore, ensuring access to public goods and services and improving their quality drives development in rural areas, especially those located remotely.

The author's own survey in the Czestochowa macroregion indicated that a substantial problem is to implement lifelong learning and professional training in rural areas. A number of young people migrate from rural areas to cities in order to improve their quality of living, which leads to a reduction in population in the country and affects the profitability in local businesses. Respondents also indicated the poor access to specialized medical, banking and educational services. Furthermore, insufficient number of competent and well-qualified employees is also observed in rural areas, which represents a threat to proper function of local enterprises in the highly-competitive market. The change in this situation requires commitment and cooperation between enterprises and local schools and institutions since opportunities for continuous learning and vocational training is of essential importance for running and developing businesses, especially in the sectors typical of rural areas, such as agriculture, forestry and fishing. Therefore, the support for lifelong learning and elimination of educational barriers in rural areas is one of the most important factors of their development. These initiatives will promote quality and effectiveness of the educational system.

The change in this state is possible through simultaneous influence on social and economic areas. One of the challenges is to take actions in rural areas with the poorest development prospects which cause a reduction in differentiation of the level of access to educational services, culture, business consulting and basic goods that determine inclusion of these areas in developmental processes. An important direction of activities is development of human resources and social capital in the locations with the lowest level and dynamics of socio-economic development. These activities should support rural inhabitants and be focused on: 
- development of social capital: support for local social initiatives,

- preventing social exclusion and social integration,

- supporting development of entrepreneurship (counselling, financial support, training),

- vocational activation of people without work (improving educational level, employment agencies, trainings, retraining schemes, improvement in quality and availability of education),

- improvement of skills and qualifications of employees (transfer of information and knowledge, exchange of experience between enterprises, cooperation, research and development),

- improved access and quality of education (development and popularization of information and knowledge, different levels of education, development of lifelong learning for adults, support for changing professions, promotion of modern methods of learning, e.g. e-learning, formal and informal learning),

- improved access to information and communication technologies, access to broadband Internet services, development of public e-services, educational initiatives (coaching) concerning social groups with lowest indices of using computers and the Internet,

- increased vocational and spacial mobility.

Therefore, in the aspect of nearest years, the development policy should consist in improving competitiveness of the economy through support for transfer of information and knowledge, absorption and creation of innovations and stimulation of development of social capital.

\section{Diffusion, transfer and absorption of information, knowledge and innovation in rural areas}

Under conditions of changing economic reality, more and more focus is on a model of open innovations, especially from the standpoint of access to knowledge and information and knowledge diffusion process. They represent one of the most important trends in contemporary economy. The main assumption of the idea of open innovation is that the enterprises can utilize not only internal research and experiences but also the solutions proposed by other entities. Instead of control over the process of innovation and closing this process, the organization derives benefits from open access to ideas through purchasing solutions from other entities through cooperation, openness and sharing.

Innovation diffusion can have a positive effect on poorly developed areas, driving changes in specialization of the regions based on traditional factors of competitiveness into innovative factors. The increase in importance of innovations as a factor of competitiveness, also in rural areas, causes that an essential component of their development is to ensure high and stable level of innovations and conditions for absorption of innovations. It is of key importance for efficiency of these activities to implement regional policies that stimulate creation, diffusion and absorption of innovations. 
In the present study, respondents were asked about the methods of transfer and diffusion of information, knowledge and innovations. In the area of the enterprise, the most frequent factors indicated by the respondents were experience and knowledge of other employees and conversations with employees (73\%). Other helpful items included reports on business activity, previous projects and initiatives implemented in the past (58\%). The employees did not use expert systems $(15 \%)$ and few of them find information from blogs or RSS channels, which was indicated by only $21 \%$ of the respondents (see figure 2 ).

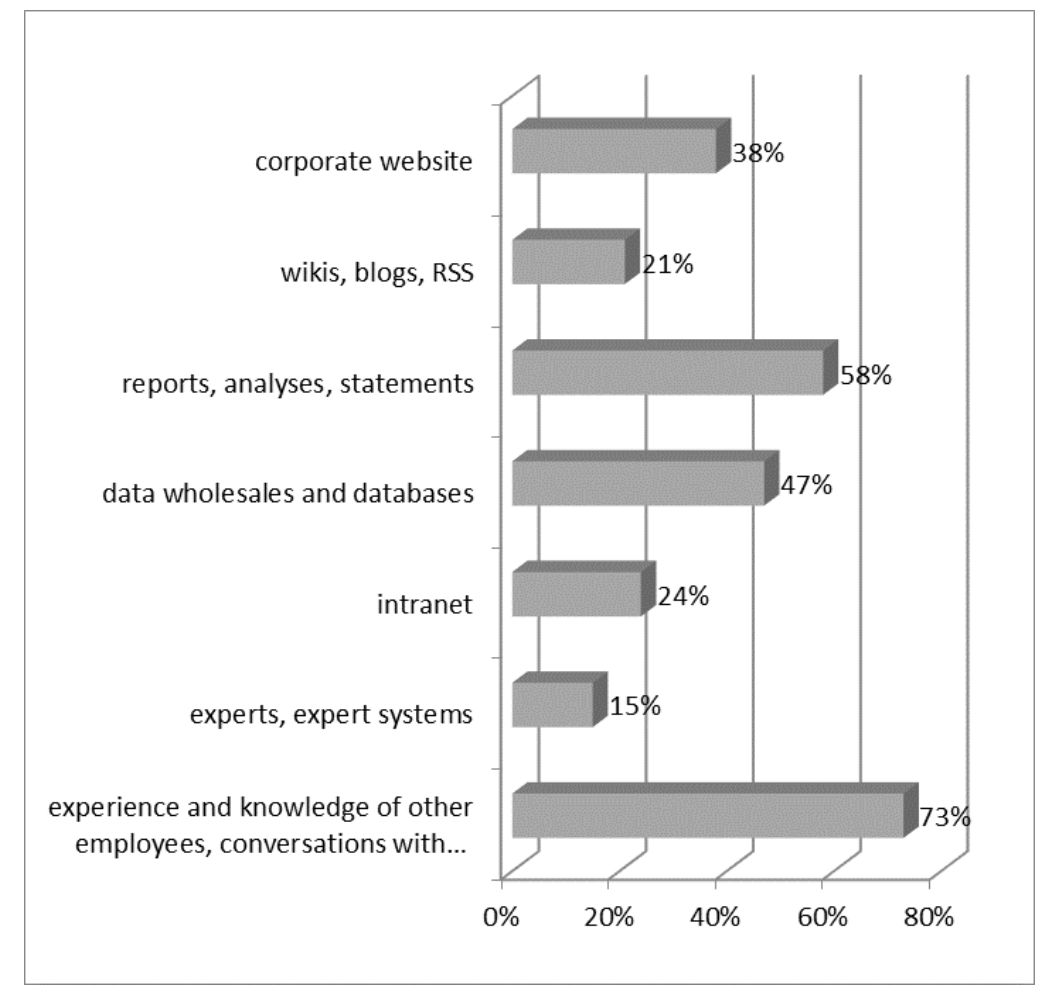

Figure 2. Methods used to ensure transfer and diffusion of information, knowledge and innovations in enterprises in rural areas

Source: Author's own elaboration.

Among the methods used to ensure transfer between the enterprise and other entities in the market, the most frequent were cyclic conversations with customers and suppliers (87\%, see figure 3 ). The most of the respondents use for this purpose various open sources, such as the Internet, social media, message boards (73\%), trainings and courses (72\%) and acts and specialized and sector-oriented journals (69\%). Entrepreneurs rarely use patents, licences and utility models, which was indicated by $8 \%$ of the respondents. External experts and consultants are also not often employed (14\%). They rarely cooperate with scientists, counsellors and research and development centres (23\%). 
The degree of creation, diffusion and implementation of knowledge depends mainly on the quality and strength of social capital in a specific area. The stronger the social and economic relations, the greater willingness to share various resources, including knowledge. In this context, rural areas have a substantial potential that results from tradition and strong local ties. Polish country participates more and more actively in a global flow of information and is affected by global tendencies, including those in the context of knowledge transfer and educational changes. Rural young people have more and more ambitious educational and material aspirations and accept contemporary challenges of the labour market concerning vocational and spatial mobility (Klemens 2015, p.7).

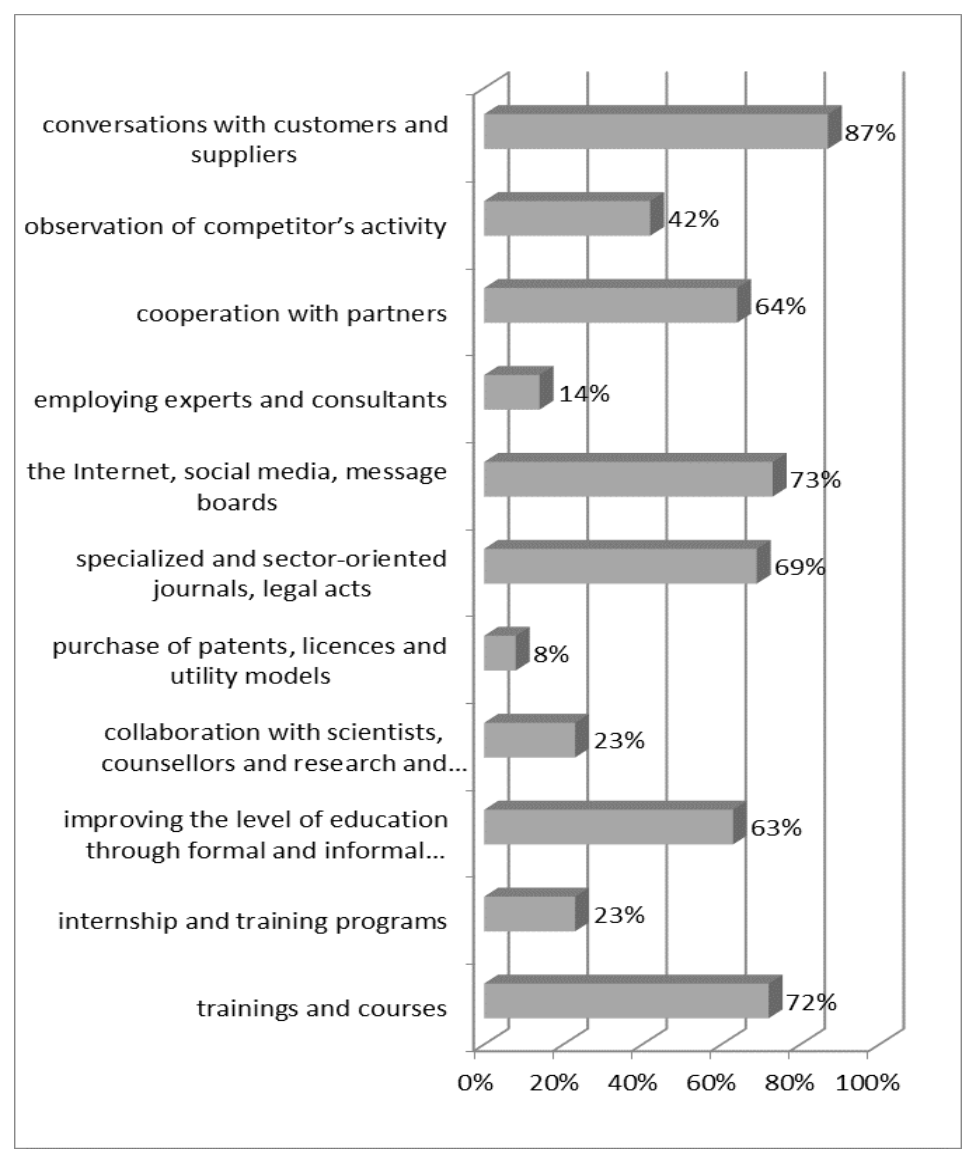

Figure 3. Methods used to ensure transfer and diffusion of information, knowledge and innovations between enterprises in rural areas

Source: Author's own elaboration.

Nowadays, processes of innovation diffusion are limited by low willingness to cooperate and low synergy of activities. However, it should be noted that popularization of innovations affects the process of learning and improving knowledge in both employees and the whole enterprise, thus strengthening the 
process of innovation diffusion. Improving diffusion effectiveness can occur through implementation of new techniques and methods to transfer information and knowledge and through improved cooperation between various entities in the market.

\section{Conclusion}

Sustainable development of rural areas largely depends on abilities to absorb innovation, acquire knowledge and skilful management of development processes. The initiatives in this area have to focus on improving the effectiveness of education, social activity, availability and mobility and systematic improvement in quality of labour resources and education, especially in rural areas since infrastructure of higher education has indicated a noticeable concentration in urban areas. It is necessary for intensification of knowledge transfer to strengthen cooperation between schools/universities and entrepreneurs and social partners and continuous emphasis on the role of knowledge and innovations, their transfer and better education in rural areas, approaching them as opportunities for improving quality of living and level of entrepreneurship. Contemporary business entities are more and more often using information technologies to support their business activities. Combination of modern technologies with conventional teaching affects the development of the learning process and opens up new opportunities which have been unavailable to potential participants before, especially those from rural areas. Therefore, it is becoming necessary to regularly promote initiatives in different areas towards improving dynamics of collaboration within development of open and active society, stimulating innovative activities in the economy, mobilization for searching for new solutions affecting socio-economic development and contributing to transfer of knowledge and innovations between enterprises.

\section{References}

1. Budinich V., Serneels S., HVC, czyli rynek, zysk i innowacje spoleczne, (in:) Odpowiedzialny biznes. Sojusz na rzecz potrzebnych zmian, HBRP nr 52012.

2. Davenport T.H., Prusak L., Working knowledge. How Organizations Manage What They Know. Harvard Business School Press, 1998, p. 17.

3. Dudek D., Perspektywy rozwoju otwartych kursów masowych w obliczu rewolucji cyfrowej w edukacji. [In:] Kiełtyka L., Jędrzejczyk W. (ed.), Wykorzystanie potencjału wspótczesnych technologii informacyjnych $w$ zarządzaniu organizacjami, Wydawnictwo Politechniki Częstochowskiej, Częstochowa 2015, p.80-88.

4. EUROPA 2020. Strategia na rzecz inteligentnego i zrównoważonego rozwoju sprzyjającego wtaczeniu społecznemu. Komunikat Komisji Europejskiej. Bruksela, 2010, p. 11-13

5. Evans Ch., Zarzadzanie wiedza. PWE, Warsaw 2005, p. 22.

6. Grudzewski W.M., Hejduk I.K., Kreowanie systemów zarzadzania wiedza podstawa osiagania przewagi konkurencyjnej współczesnych przedsiębiorstw [in:] Grudzewski W.M., Hejduk I.K. (red.), Przedsiębiorstwo przyszłości - wizja strategiczna. Difin, Warsaw 2002, p. 16.

7. Grudzewski W.M., Hejduk I.K., Zarzadzanie wiedza w przedsiębiorstwach. Difin, Warsaw 2004, p. $75-76$. 
8. Kaczmarek B., Koncepcje klasyfikacji i zarzadzania kapitatem intelektualnym przedsiębiorstwa. [in:] Czerwińska M. (ed.): Zarządzanie kapitałem intelektualnym. Istota, pomiar i instrumenty wdrażania. Fundacja rozwoju Uniwersytetu Gdańskiego, Gdansk 2007, p. 15.

9. Kisielnicki J., System pozyskiwania i zarządzania wiedza we współczesnych organizacjach. [in:] Zarządzanie wiedza we współczesnych organizacjach. Ed. Kisielnicki J., WSHiP im. R. Łazarskiego, Warsaw 2003, p. 17.

10. Klemens B., Znaczenie transferu wiedzy i edukacji dla rozwoju obszarów wiejskich, Acta Universitatis Lodziensis, Folia Geographica Socio-Oeconomica 20, 2015, 5-23, p. 7.

11. Krajowa Strategia Rozwoju Regionalnego 2010-2020: Regiony, Miasta, Obszary Wiejskie Ministerstwo Rozwoju Regionalnego, Warsaw, 2010, p. 5.

12. Kulej-Dudek E., Rola informacji, wiedzy oraz technologii informacyjnej $w$ zarzadzaniu małym i średnim przedsiębiorstwem. [in:] Kościelniak H. (ed.), Przedsiębiorczość szanse $i$ wyzwania Wyd. WZ Politechniki Częstochowskiej, Czestochowa 2012, p. 94-111.

13. Lis T., Brzozowska A., Korombel A., Knowledge Management in an Enterprise as a Response to Contemporary Customers 'Needs, Department of Computers and Informatics, FEEI TU of Kosice, Kosice 2013, p. 262-267.

14. Probst G., Raub S., Romhardt K., Zarządzanie wiedza w organizacji. Oficyna Ekonomiczna, Krakow 2002, p. 35.

15. Program rozwoju obszarów wiejskich na lata 2014-2020, Ministerstwo Rolnictwa i Rozwoju Wsi, Warsaw, p. 79, 81, 156.

16. Sałek R., Istota oraz znaczenie zagadnienia innowacji $w$ rozwoju przedsiębiorstw [in:] Współczesne problemy zarządzania przedsiębiorstwami. Teoria $i$ praktyka, Wyd. WZ Politechniki Częstochowskiej, Czestochowa 2013, p. 90-101.

17. Skrzypek E., Wycena wiedzy i kapitału intelektualnego $i$ ich wpływ na efektywność organizacji. [in:] Z. Szyjewski, Nowak J., Grabara J. (ed.): Strategie informatyzacji i zarzadzanie wiedza. WNT, Warsaw 2004, p. 14.

18. Stanowisko Ogólnopolskiej Federacji Organizacji Pozarządowych w sprawie innowacji społecznych w przyszłym okresie programowania funduszy europejskich 2014-2020, Warsaw 2012, p. 1.

19. Zasady gromadzenia $i$ interpretacji danych dotyczacych innowacji. Podręcznik Oslo, Publikacja OECD I Eurostatu, Warsaw 2008, p. 49-53.

\section{TRANSFER INFORMACJI, WIEDZY I INNOWACJI NA OBSZARACH WIEJSKICH}

Streszczenie: W rozdziale zaprezentowano pojęcie i rolę informacji, wiedzy i innowacji w aspekcie rozwoju gospodarczego. Wyróżniono główne rodzaje innowacji. Określono działania na rzecz realizacji strategii w zakresie inteligentnego i zrównoważonego rozwoju. Opisano wyzwania i priorytety wspólnej polityki rozwoju regionów ze szczególnym uwzględnieniem obszarów wiejskich. Wskazano także na badania własne w zakresie dyfuzji, transferu i absorpcji informacji, wiedzy i innowacji na obszarach wiejskich.

Słowa kluczowe: informacja, wiedza, innowacje, transfer, dyfuzja, obszary wiejskie 